\title{
6. 気管・気管支軟化症に対する治療法の検討
}

○鎌田 振吉, 臼井 規朗, 野瀬 恵介, 田附 裕子, 神山 雅史, 福澤 正洋

\author{
（大阪大学小児外科）
}

気管・気管支軟化症では，未だ治療に難渋す る症例もみられ，教室での治療例を検討した。 【対象】1992年以降に経験した21症例で, 殆ど の症例が合併疾患を有していた。診断は臨床症 状に加え, 全麻下気道ファイバー検査にて行い, 用手換気下呼気時に気道内腔の狭小化の程度が 著しいものを手術適応とした。

【結果】大血管固定術施行17例中臨床症状の改 善が明かでなかった症例は 4 例でいずれも左主 気管支に病変を有し, 術中ファイバーでの改善
評価に一致していた。左主気管支に外ステント を行った 1 例では, 気管支壁の器質的変化のた め内腔の十分な開大が得られなかった。内ステ ント 6 例 (Palmaz 3 例, Dumon 3 例) 中全例 に肉芽の増生をみたが, 3 例は肉芽のコントロ ールが可能で, 臨床症状の改菩がみられた。

【結論】左主気管支末梢側に病変が及ぶ症例で は，大血管固定術のみで改善が見られないもの もあり, 治療法の検討が必要である。 